\title{
Keluarga Peduli Stunting Sebagai Family Empowerment Strategy Dalam Penurunan Kasus Stunting di Kabupaten Blora
}

\author{
Denis 0xy Handika*1 \\ ${ }^{1}$ Program Studi Kesehatan Masyarakat, Fakultas Kesehatan Masyarakat, Universitas Diponegoro \\ *e-mail: oxy.handika30@gmail.com
}

\begin{abstract}
Stunting is a form of growth faltering due to chronic nutrient deficiency that lasts from the womb until the age of 24 months. This situation not only makes the children height short but also manifests an increase in children's morbidity and mortality, as well as children's cognitive, motor, and verbal development which is not optimal it ultimately results in low human resources. Family-based intervention can be an effective step in helping the government reduce the prevalence of stunting. By using the participatory action method in the implementation of empowering family activity for stunting, the people of Jomblang Village, Jepon District, Blora Regency are equipped with knowledge about strengthening 1000 HPK, screening stunting independently, optimizing exclusive breastfeeding, processing breast milk and making MP-ASI based on available resources. around the place of residence. The results of this devoted family empowerment service devotion are increasing community understanding of stunting, 1000 HPK, exclusive breastfeeding, skills in processing milk and community independence skills in making MP-ASI Sujaka.
\end{abstract}

Keywords: Stunting, Family Empowerment, Prevention

\begin{abstract}
Abstrak
Stunting merupakan bentuk kegagalan pertumbuhan (growth faltering) akibat defisiensi nutrient kronis yang berlangsung sejak masih dalam kandungan hingga berusia 24 bulan. Keadaan ini bukan hanya saja membuat tinggi badan anak menjadi pendek, namun juga bermanifestasi meningkatnya morbiditas dan mortalitas anak, serta perkembangan kognitif, motorik dan verbal anak tidak optimal yang pada akhirnya mengakibatkan rendahnya sumber daya manusia. Upaya intervesi berbasis keluarga (family empowerment) dapat menjadi salah satu langkah yang efektif dalam membantu pemerintah menurunkan prevalensi kasus stunting. Dengan menggunakan metode participatory action dalam pelaksanaan kegiatan pemberdayaan keluarga peduli stunting, masyarakat Desa Jomblang, Kecamatan Jepon, Kabupaten Blora dibekali ilmu mengenai penguatan 1000 HPK, screening stunting secara mandiri, pengoptimalisasian ASI eksklusif, pengolahan ASI perah serta pembuatan MP-ASI berbasis sumberdaya yang tersedia disekitar tempat tinggal. Hasil dari pengabdian pemberdayaan keluarga peduli stunting ini adalah meningkatnya pemahaman masyarakat terhadap stunting, 1000 HPK, ASI eksklusif, ketrampilan dalam mengolah ASI perah serta keterampilan kemandirian masyarakat dalam pembuatan MP-ASI Sujaka.
\end{abstract}

Kata kunci: Stunting, Pemberdayaan Keluarga, Pencegahan

\section{PENDAHULUAN}

Hingga Hingga saat ini, permasalahan kesehatan yang berkaitan dengan gizi masih perlu diwaspadai, terutama bagi negara berkembang termasuk Indonesia (Astuti, Megawati, \& CMS, 2018). Karena, permasalahan kesehatan yang berkaitan dengan gizi merupakan prediktor buruknya kualitas sumber daya manusia yang selanjutnya akan berpengaruh pada pengembangan potensi bangsa (UNICEF, 2013).

Manifestasi asupan gizi yang cukup dan seimbang adalah keberhasilan tumbuh kembang anak yang optimal. Asupan gizi yang baik sangat diperlukan dalam periode emas pertumbuhan dan perkembangan anak. Periode emas dimulai sejak anak masih di dalam kandungan hingga usia dua tahun atau yang sering disebut dengan istilah seribu hari pertama kehidupan anak (1000 HPK). Kekurangan gizi yang terjadi pada periode emas tersebut dapat menyebabkan berbagai masalah, salah satunya adalah masalah gagal tumbuh dan berkembang sehingga anak menjadi lebih pendek dari standar rata - rata anak seusianya (Teja, 2019).

Stunting merupakan bentuk kegagalan pertumbuhan (growth faltering) akibat defisiensi nutrient kronis yang berlangsung selama lama sejak anak dalam kandungan hingga berusia 24 
bulan (Mitra, 2015). Keadaan ini membuat tinggi badan seseorang lebih pendek jika dibandingkan dengan tinggi badan orang lain yang sebaya dengannya (Tentama, Delfores, Wicaksono, \& Fatonah, 2018). Penggolongan stunting dapat dipresentasikan berdasarkan standar pertumbuhan menurut World Health Organization (WHO). Standar pertumbuhan menurut WHO tersebut menggunakan kriteria z-score panjang atau tinggi badan anak menurut umur berada di bawah minus dua standar deviasi (Ni'mah \& Nadhiroh, 2015).

Stunting memiliki dampak yang cukup serius bagi jangka pendek dan panjang. Dampak jangka pendek diantaranya adalah peningkatan morbiditas dan mortalitas anak, perkembangan kognitif, motorik dan verbal anak tidak optimal, serta peningkatan pembiayaan kesehatan. Dampak jangka panjang adalah postur tubuh yang tidak optimal (lebih pendek), gangguan metabolik, penurunan fungsi imun, meningkatkan risiko obesitas, penyakit degenerative, menurunkan kesehatan reproduksi, kapasitas belajar/kerja, produktivitas, dan performa kurang optimal (Mutiara, Apriliana, Suwandi, \& Utami, 2019).

Data prevalensi anak balita stunting yang dirilis oleh WHO pada tahun 2018 menyebutkan Indonesia termasuk ke dalam negara ketiga dengan prevalensi tertinggi di South-East Asian Region setelah Timor Leste (50,5\%) dan India (38,4\%) yaitu sebesar 36,4\%). Sedangkan berdasarkan Hasil Riset Kesehatan Dasar Tahun 2018, prevalensi stunting di Indonesia mencapai 30,8 \% (Kemenkes RI, 2018). Untuk prevalensi stunting Provinsi Jawa Tengan sebesar 31,75\% dan mengerucut ke Kabupaten Blora sebesar 32,86\%. Tentu angka ini masih di atas capaian target WHO, yang menargetkan data prevalensi stunting di bawah 20\% (Balitbangkes RI, 2019).

Tingginya angka prevalensi stunting di Indonesia, tentu saja menjadi perhatian pemerintah. Berbagai upaya dilakukan demi penurunan angka stunting di Indonseia, termasuk dengan mengeluarka "Strategi Nasional Percepatan Pencegahan Anak Kerdil (Stunting) Periode 2018 - 2024". Keseriusan pemerintah dalam menekan angka stunting tentusaja perlu kerjasama dari perbagai pihak pula, termasuk dukungan dari masyarakat. Upaya intervesi berbasis keluarga (family empowerment) dapat menjadi salah satu langkah yang efektif dalam penurunan kasus stunting ini.

Keluarga merupakan lingkungan sosial pertama dan utama bagi tumbuh kembangnya anak. Anak akan berkembang optimal apabila mereka mendapatkan stimulasi yang baik dari keluarga. Keluarga memiliki fungsi sosial yaitu: mencari nafkah, memberi pendidikan, memberi perlindungan dan bermasyarakat. Pemanfaatan berbagai potensi sumberdaya yang dimiliki keluarga untuk mengatasi permasalahan yang dihadapi jauh lebih efektif dan potensial dibandingkan mengembangkan potensi lain yang sesungguhnya belum atau tidak mereka miliki. Oleh karena itu model pemberdayaan keluarga dianggap tepat (Na'imah \& Suwarti, 2016).

Secara umum terdapat beberapa faktor penghambat dalam melakukan pemberdayaan keluarga, yaitu ketidakadekuatan informasi serta keterampilan keluarga dalam mengelola sumberdaya yang telah tersedia. Maka dari itu, pemberdayaan Keluarga Peduli Stunting dimaksudkan untuk meningkatkan pemahamana serta ketrampilan masyarakat Blora dalam pencegahan kasus stunting.

\section{METODE}

Metode yang digunakan dalam pelaksanaan kegiatan pemberdayaan keluarga peduli stunting adalah participatory action yang didukung dengan presentasi dan Forum Group Discussion (FGD). Dimana pencarian akar masalah serta prioritas kebutuhan masyarakat dilakukan bersama dengan masyarakat.

Kegiatan pengabdian ini dilaksanakan di Desa Jomblang, Kecamatan Jepon Kabupaten Blora pada tanggal 9 Januari - 13 Februari 2020. Diawali dengan melakukan observasi lapangan dan wawancara pendahuluan kepada kepala desa, kader posyandu serta beberapa ibu yang memiliki anak balita. Langkah ini sangat penting dilakukan guna perancangan program yang sesuai dengan permasalahan, kebutuhan serta kapasitas masyarakat. 
Langkah Selanjutnya adalah pelaksanaan program pemberdayaan keluarga peduli stunting yang dilakukan secara bertahap. Tahap pertama diawali dengan penyuluhan mengenai 1000 HPK dan stunting, lalu dilanjutkan pengukuran antropometri anak balita untuk mengetahui status gizi dari balita. Tahap kedua adalah penyuluhan mengenai ASI eksklusif dan ASI perah. Tahap ketiga adalah demonstrasi pembuatan MP-ASI. Pada setiap tahapan, dilakukan pula prestest dan post-test untuk mengukur tingkat pemahaman partisipan.

\section{HASIL DAN PEMBAHASAN}

\subsection{Observasi Lapangan dan Wawancara Pendahuluan}

Observasi lapangan dilakukan dengan meninjau langsung ke wilayah tempat kegiatan akan dilaksanakan yaitu Desa Jomblang, Kecamatan Jepon, Kabupaten Blora. Saat dilakukan peninjauan, juga dilakukan koordinasi sekaligus wawancara dengan kepala desa, kader posyandu dan sebagian ibu yang memiliki anak balita guna memperoleh data permasalahan, kebutuhan masyarakat desa serta sumber daya alam yang dapat dimanfaatkan.

Gambaran demografis Desa Jomblang secara umum adalah mayoritas penduduk bermata pencaharian sebagai petani karena sebagian besar lahan/pertanahan di Desa Jomblang adalah persawahan dan tegalan. Mereka berangkat ke sawah/ladang pada pagi hari mulai pukul 06.30 10.30 WIB ataupun pada sore hari pada pukul 15.00 - 17.00 WIB. Jenis pertanian yang menjadi unggulan adalah Jagung karena daerah mereka termasuk daerah yang kesulitan air ketika musim kemarau.

Untuk sarana kesehatan ibu dan anak, terdapat empat Posyandu yang dijalankan di Desa Jomblang, yaitu Poyandu Anggrek I dengan cakupan wilayah kerja RW 1, Posyandu Anggrek II dengan cakupan wilayah kerja RW 2, Posyandu Anggrek III dengan cakupan wilayah kerja RW 3, dan Posyandu IV dengan cakupan wilayah kerja RW 3 (Dusun Kali Klampok). Posyandu dilaksanakan empat kali dalam satu bulan secara bergiliran mengingat keterbatasan kader kesehatan.

Sedangkan untuk sumber daya alam, jagung dan daun kelor sangat berpotensi untuk dimanfaatkan dalam pembuatan program penanganan stunting melalui pembuatan MP-ASI. Jagung merupakan produk unggulan di Desa Jomblang, produksinya sangat melimpah namun belum dimanfaatkan secara maksimal dalam hal pemenuhan gizi anak balita/MP-ASI. Masyarakat Desa Jomblang mengolah jagung biasanya dibuat nasi jagung dan jajanan marning jagung. Daun kelor hampir sebagian besar penduduk menanam kelor di sekitar pekarangan rumah. Penduduk biasanya memanfaatkan kelor untuk dibuat jamu dengan cara merebusnya dan meminum ekstraknya.

\subsection{Penguatan 1000 HPK}

Penyuluhan dilakukan di Balai Desa Jomblang dalam dua kali waktu dengan jumlah total masyarakat yang terlibat sebanyak 117 partisipan. Pelaksanaan pertama untuk wilayah kerja Posyandu Anggrek I dan II, sedangkan pelaksaan kedua untuk wilayah kerja Posyandu Anggrek III dan IV. Partisipan terdiri dari PUS (pasangan usia subur), Ibu hamil, Ibu menyusui, Ibu balita, lansia dan kader posyandu. Penyuluhan ini dilaksanakan dengan menggunakan teknik presentasi, pemutaran video dan FGD. Tujuan dari tahap ini adalah agar meningkatnya pemahaman keluarga mengenai stunting dan $1000 \mathrm{HPK}$.

Materi penyuluhan diawali dengan pemberian pengetahuan tentang pengertian stunting, fakta data kasus stunting, penyebab stunting, dampak stunting, cara mencegah stunting dan kemudian dilanjutkan dengan pemberian materi tentang pengertian 1000 HPK, tahapan perkembangan dan pertumbuhan anak serta langkah yang seharusnya dilakukan orang tua dan keluarga.

Sebelum materi diberikan, panitia membagikan lembaran tes awal (pre-test) kepada para partisipan untuk dikerjakan dan setelah pemberian materi selesai, panitia membagikan kembali 
lembar tes (post-test) untuk mengukur tingkat pemahaman partisipan. Berdasarkan hasil test yang dilakukan, kegiatan penyuluhan ini mampu meningkatkan pemahaman peserta mengenai materi yang diberikan (tabel 1).

Tabel 1. Nilai Pre-test dan Post-test Penyuluhan Penguatan 1000 HPK

\begin{tabular}{clcc}
\hline No & Indikator & Nilai Pre-test & Nilai Post-test \\
\hline 1 & Pengertian stunting & $37 \%$ & $89 \%$ \\
2 & Penyebab stunting & $42 \%$ & $84 \%$ \\
3 & Dampak stunting & $47 \%$ & $92 \%$ \\
4 & Pengertian 1000 HPK & $35 \%$ & $90 \%$ \\
5 & Tahapan tumbuh kembang anak & $30 \%$ & $75 \%$ \\
6 & Peran keluarga dalam tumbuh kembang anak. & $53 \%$ & $88 \%$ \\
\hline
\end{tabular}

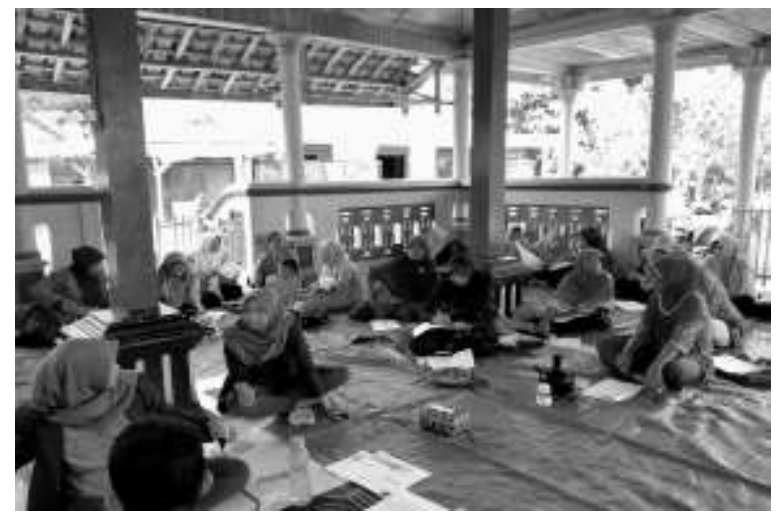

Gambar 1. Penyuluhan Penguatan 1000 HPK

\subsection{Screening Stunting}

Kegiatan screening stunting kepada 101 balita yang dilakukan bersamaan dengan pelaksanaan posyandu bulanan di setiap RW. Sebelumnya juga telah diberikan himbauan untuk seluruh penduduk yang memiliki anak balita untuk menghadiri kegiatan posyandu karena akan adanya kegiatan screening stunting. Pengukuran atropometri yang dilakukan adalah mengukur tinggi badan/panjang badan anak dan berat badan anak lalu membandingkannya dengan standar pertumbuhan menurut World Health Organization (WHO) dengan indeks Berat Badan Menurut Umur (BB/U), Tinggi Badan/Panjang Badan Menurut Umur (TB/U atau PB/U), dan Indeks Massa Tubuh menurut Umur (IMT/U). Kategori status gizi untuk indeks BB/U adalah gizi buruk, kurang, baik, dan lebih. Data pemeriksaan berdasarkan indeks BB/U dapat dilihat pada table 2.

Tabel 2. Status Gizi Balita Berdasarkan BB/U

\begin{tabular}{lll}
\hline No & Kategori BB/U & Jumlah(N) \\
\hline 1 & Gizi buruk & $2(1,98 \%)$ \\
2 & Gizi kurang & $15(14,85 \%)$ \\
3 & Gizi baik & $77(76,24 \%)$ \\
4 & Gizi lebih & $7(6,93 \%)$ \\
\hline
\end{tabular}

Berdasarkan table 2, didapatkan data bahwa terdapat anak balita dengan kategori underweight sejumlah 17 balita (16,83\%) dari keseluruhan 101 balita. Seorang anak dapat dikategorikan underweight ketika hasil penghitungan BB/U nilai Z-score <-2SD di bawah standar pertumbuhan WHO. Underweight adalah keadaan gizi kurang yang terjadi akibat kurangnya asupan zat gizi yang masuk ke dalam tubuh atau dapat pula disebut ganguan gizi akut.

Kategori status gizi untuk indeks TB/U atau PB/U adalah sangat pendek, pendek dan normal. Data pemeriksaan berdasarkan indeks TB/U atau PB/U dapat dilihat pada table 3. 
Tabel 3. Status Gizi Balita Berdasarkan TB/U Atau PB/U

\begin{tabular}{lll}
\hline No & Kategori TB/U atau PB/U & Jumlah(N) \\
\hline 1 & Sangat pendek & $8(7,92 \%)$ \\
2 & pendek & $16(15,84 \%)$ \\
3 & Normal & $77(76,24)$ \\
\hline
\end{tabular}

Berdasarkan table 3, didapatkan data bahwa terdapat anak balita dengan kategori stunting sejumlah 24 balita (23,76\%) dari keseluruhan 101 balita. Seorang anak dapat dikategorikan stunting ketika hasil penghitungan TB/U nilai Z-score <-2SD di bawah standar pertumbuhan WHO. Stunting merupakan masalah gizi kronis yang disebabkan oleh asupan gizi yang kurang dalam waktu yang cukup lama.

Sedangkan untuk kategori status gizi untuk indeks IMT/U adalah sangat kurus, kurus, normal dan gemuk. Data pemeriksaan berdasarkan indeks IMT/U dapat dilihat pada table 4.

Tabel 4. Status Gizi Balita Berdasarkan IMT/U

\begin{tabular}{lll}
\hline No & Kategori IMT/U & Jumlah(N) \\
\hline 1 & Sangat kurus & $3(2,97 \%)$ \\
2 & Kurus & $6(5,94 \%)$ \\
3 & Normal & $84(83,17)$ \\
4 & Gemuk & $8(7,92 \%)$ \\
\hline
\end{tabular}

Berdasarkan table 4, didapatkan data bahwa terdapat anak balita dengan kategori wasting sejumlah 24 balita $(23,76 \%)$ dari keseluruhan 101 balita. Seorang anak dapat dikategorikan wasting ketika hasil penghitungan IMT/U nilai Z-score <-2SD di bawah standar pertumbuhan WHO. Wasting merupakan masalah gizi akut yang disebabkan oleh asupan gizi yang kurang.

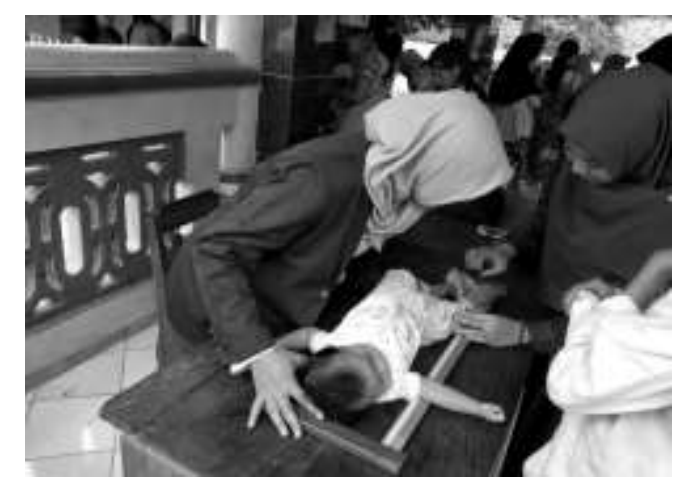

Gambar 2. Pengukuran Panjang Badan Balita

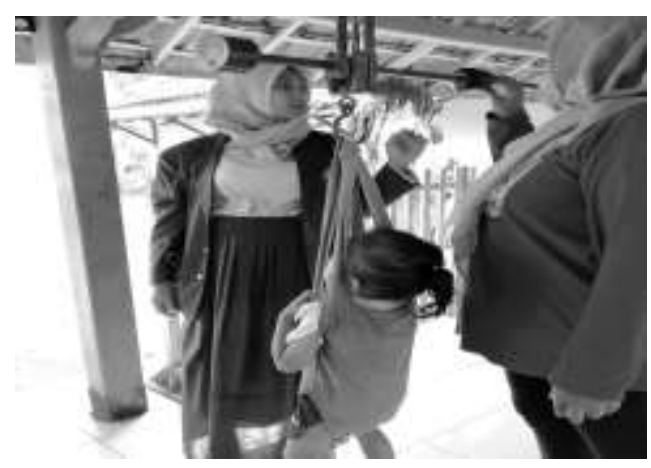

Gambar 3. Pengukuran Berat Badan Balita

\subsection{Optimalisasi ASI Eksklusif}


Penyuluhan dilakukan bersamaan dengan pelaksanaan Posyandu bulanan di setiap RW dengan jumlah total masyarakat yang terlibat sebanyak 86 partisipan. Partisipan terdiri dari PUS (pasangan usia subur), Ibu hamil, Ibu menyusui, Ibu balita dan kader posyandu. Penyuluhan ini dilaksanakan dengan menggunakan teknik presentasi, pemutaran video dan FGD. Tujuan dari tahap ini adalah agar meningkatnya pemahaman dan ketrampilan keluarga mengenai ASI eksklusif dan ASI perah.

Materi penyuluhan diawali dengan pemberian pengetahuan tentang pengertian ASI eksklusif, manfaat ASI eksklusif, dampak apabila anak tidak mendapatkan ASI eksklusif, langkah pengoptimalan ASI eksklusif dengan ASI perah, pemilihan wadah dan penyimpanan ASI perah serta pengolahan ASI perah.

Sebelum materi diberikan, panitia membagikan lembaran tes awal (pre-test) kepada para partisipan untuk dikerjakan dan setelah pemberian materi selesai, panitia membagikan kembali lembar tes (post-test) untuk mengukur tingkat pemahaman partisipan. Berdasarkan hasil test yang dilakukan, kegiatan penyuluhan ini mampu meningkatkan pemahaman peserta mengenai materi yang diberikan (tabel 5).

Tabel 5. Nilai Pre-test dan Post-test Penyuluhan Optimalisasi ASI Eksklusif

\begin{tabular}{clcc}
\hline No & Indikator & Nilai Pre-test & Nilai Post-test \\
\hline 1 & Pengertian ASI eksklusif & $44 \%$ & $85 \%$ \\
2 & Manfaat ASI eksklusif & $57 \%$ & $84 \%$ \\
3 & Dampak anak tidak & $73 \%$ & $90 \%$ \\
& mendapatkan ASI Eksklusif & & \\
4 & Pengertian ASI perah & $69 \%$ & $75 \%$ \\
5 & Pemilihan wadah & $40 \%$ & $75 \%$ \\
6 & Penyimpanan ASI perah & $65 \%$ & $88 \%$ \\
7 & Pengolahan ASI perah. & $55 \%$ & $75 \%$ \\
\hline
\end{tabular}

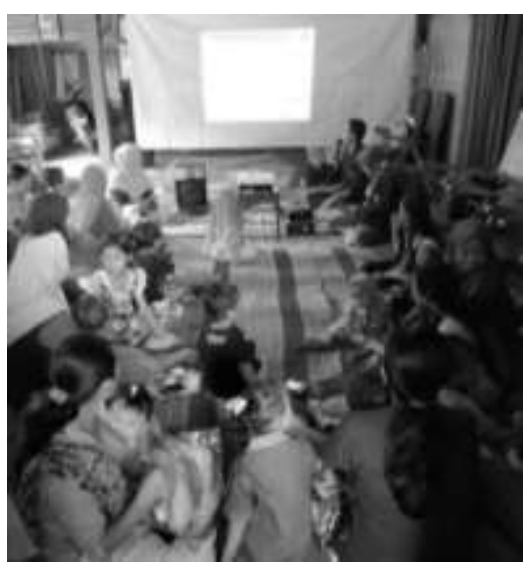

Gambar 4. Penyuluhan Penguatan ASI Eksklusif

\subsection{MP-ASI}

Demostrasi pembuatan MP-ASI dilakukan di Balai Desa Jomblang dalam dua kali waktu dengan jumlah total masyarakat yang terlibat sebanyak 87 partisipan. Pelaksanaan pertama untuk wilayah kerja Posyandu Anggrek I dan II, sedangkan pelaksaan kedua untuk wilayah kerja Posyandu Anggrek III dan IV. MP-ASI yang dibuat adalah Sujaka (Susu jagung kacang), yang memiliki rasa manis dan bertekstur sedikit kental. Melihat dari sumber daya alam berupa hasil pertanian berupa jagung yang sangat melimpah, maka inovasi ini muncul guna pemanfaatan SDA yang telah tersedia untuk peningkatan asupan gizi balita dalam penurunan kasus stunting. Pada kegiatan Posyandu bulanan selanjutnya yaitu pada bulan Februari, dilakukan pemberian MP-ASI Sujaka kepada balita. Terlihat mereka sangat menyukai MP-ASI Sujaka. 


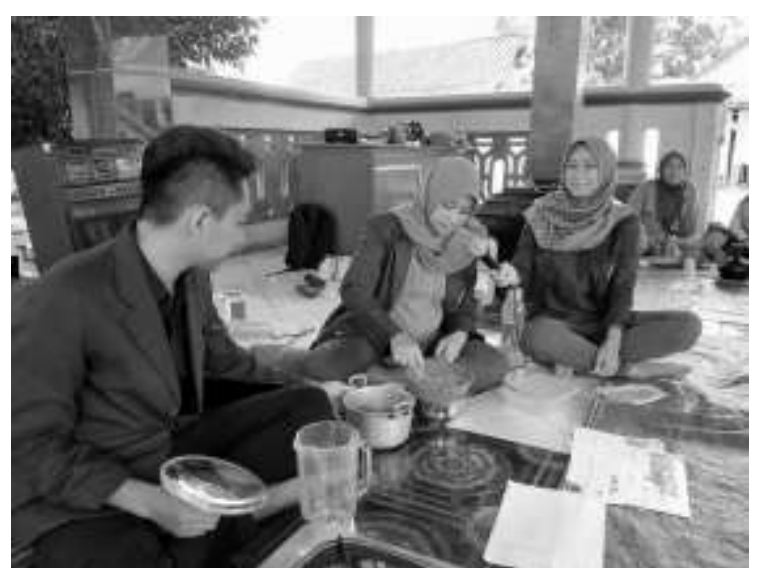

(a)

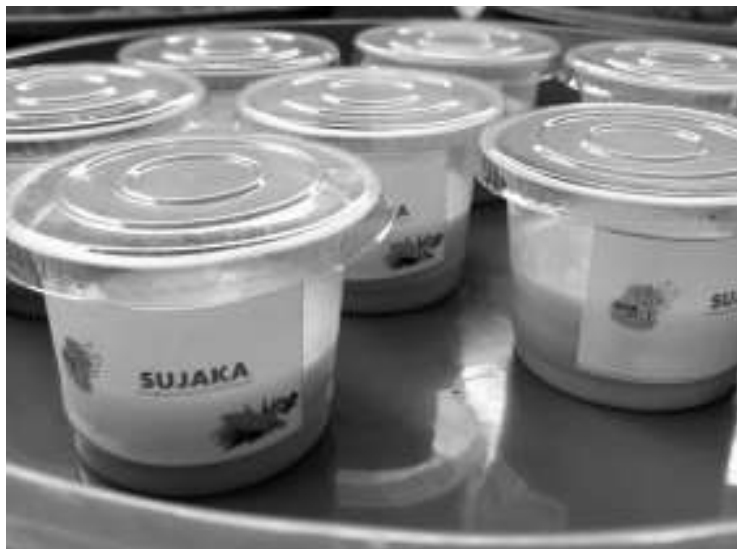

(b)

Gambar 5. (a) Demonstrasi Pembuatan MP-ASI Sujaka, (b) MP-ASI Sujaka

\section{KESIMPULAN}

Setelah kegiatan pengabdian pemberdayaan keluarga peduli stunting dilaksanakan, didapatkan hasil antara lain:

1. Meningkatnya pemahaman masyarakat terhadap penyebab stunting, dampak stunting, tahapan pertumbuhan dan perkembangan anak serta langkah yang harus dilakukan orang tua dan keluarga dalam mendukung optimalisasi tumbuh kembang anak, serta pentingnya ASI eksklusif.

2. Meningkatnya ketrampilan kemandirian masyarakat dalam mengolah ASI perah serta dalam pembuatan MP-ASI Sujaka dari sumberdaya yang tersedia di sekitar lingkungan tempat tinggal.

\section{SARAN}

Untuk kedepannya diharapkan keluarga lebih aktif dalam mengaplikasikan ilmu yang telah dipahami guna memantau dan mengawal pertumbuhan dan perkembangan anak sehingga. Selain itu juga perlu adanya eksplorasi lebih dalam mengenai sumber daya alam lainnya yang dapat dijadikan sebagai tambahan gizi sebagai langkah intervensi gizi sejak dini sehingga dapat membantu dalam pencegahan kasus stunting.

\section{UCAPAN TERIMA KASIH}

Penulis mengucapkan terima kasih kepada Lembaga Penelitian dan Pengabdian kepada Masyarakat (LPPM) Universitas Diponegoro, Dinas Kesehatan Kabupaten Blora, Masyarakat Desa Jomblang serta seluruh pihak yang secara langsung maupun tidak langsung telah membantu dalam pelaksaan kegiatan pengabdian pemberdayaan Keluarga Peduli Stunting.

\section{DAFTAR PUSTAKA}

Astuti, S., Megawati, G., \& CMS, S. (2018). Gerakan Pencegahan Stunting Melalui Pemberdayaan Masyarakat di Kecamatan Jatinangor Kabupaten Sumedang. Jurnal Aplikasi Ipteks Untuk Masyarakat, 7(3), 185-188. $\quad$ Retrieved from http://jurnal.unpad.ac.id/dharmakarya/article/view/20034/10338

Balitbangkes RI. (2019). Laporan Provinsi Jawa Tengah RISKESDAS 2018. Retrieved April 22, 2020, from https://dinkesjatengprov.go.id/v2018/storage/2019/12/CETAK-LAPORANRISKESDAS-JATENG-2018-ACC-PIMRED.pdf 
Kemenkes RI. (2018). Hasil Utama RISKESDAS 2018. Retrieved April 22, 2020, from http://kesmas.kemkes.go.id/assets/upload/dir_519d41d8cd98f00/files/Hasil-riskesdas2018_1274.pdf

Mitra, M. (2015). Permasalahan Anak Pendek (Stunting) dan Intervensi untuk Mencegah Terjadinya Stunting (Suatu Kajian Kepustakaan). Jurnal Kesehatan Komunitas, 2(6), 254261. https://doi.org/10.25311/jkk.vol2.iss6.85

Mutiara, H., Apriliana, E., Suwandi, J. F., \& Utami, N. (2019). Screening Pertumbuhan Anak , Edukasi tentang Stunting serta Pelatihan Pemantauan Pertumbuhan Anak pada Orang Tua Siswa Sekolah Dasar Negeri di Provinsi Lampung dalam Upaya Meningkatkan Derajat Kesehatan Anak Indonesia. Jurnal Pengabdian Masyarakat, 4(1), 1-5.

Na'imah, T., \& Suwarti. (2016). Model Pemberdayaan Keluarga Dengan Pendekatan Improvement Dan Berbasis Masalah Psikososial Anak Dari Keluarga Miskin. Jurnal Nasional UMP, XIII(1), 83-90. Retrieved from http://pfm.depsos.go.id

Ni'mah, K., \& Nadhiroh, S. R. (2015). Faktor Yang Berhubungan Dengan Kejadian Stunting Pada Balita. Media Gizi Indonesia, 10(1), 13-19. https://doi.org/10.20473/MGI.V10I1.13-19

Teja, M. (2019). Stunting Balita Indonesia dan Penanggulangannya (Vol. 11).

Tentama, F., Delfores, H. D. L., Wicaksono, A. E., \& Fatonah, S. F. (2018). Penguatan Keluarga Sebagai Upaya Menekan Angka Stunting dalam Program Kependudukan, Keluarga Berencana dan Pembangunan Keluarga (KKBPK). Jurnal Pemberdayaan: Publikasi Hasil Pengabdian Kepada Masyarakat, 2(1), 113. https://doi.org/10.12928/jp.v2i1.546

UNICEF. (2013). Improving Child Nutrition The Achievable Imperative For Global Progress. Retrieved from www.unicef.org/publications/index.html 